\title{
Knowledge of Pupils with Special Educational Needs and Inclusion in Teachers at Common Primary Schools
}

\author{
Ivana Horváthová, Dita Finková
}

\begin{abstract}
This paper presents empirical findings on knowledge concerning pupils with special educational needs in primary school teachers. We identified the problematic areas as those with confirmed weaknesses. We also pointed out teachers' interest in education in the field of special educational needs. The main finding was that teachers missed some important information and knowledge of special educational needs in integrated pupils, and methods of inclusion. The paper documents the need to continually improve institutional education focused on pupils' special educational needs. Especially, increasing the quality of professional-methodological as well as generally-pedagogical preparation of future educators as a key role is most demanded.
\end{abstract}

Key words: life-long education, special educational needs, integrated pupil, inclusion

\section{Abstrakt}

Článek přináší empirické poznatky o znalostech učitelů na „běžných“ základních školách o žácích se speciálními vzdělávacími potřebami. V práci jsme identifikovali oblasti, kterých se nedostatky týkaly. Dále jsme poukázali na zájem pedagogů o vzdělávání 
v oblasti speciálních vzdělávacích potřeb. Hlavním zjištěním bylo, že pedagogům chybí některé důležité informace, poznatky o speciálních vzdělávacích potřebách integrovaného žáka a začlenění. V práci jsme určili oblasti, kterých se nedostatky týkaly. Poukázali na zájem pedagogů o vzdělávání v oblasti speciálních vzdělávacích potřeb. Práce dokazuje, že je třeba neustále zlepšovat institucionální vzdělávání se zaměřením na speciální vzdělávací potřeby žáků. Zejména zvyšovat kvalitu odborně-metodické, stejně i obecně pedagogické přípravy pedagogů.

Klíčová slova: celoživotní vzdělávání, speciální vzdělávací potřeby, integrovaný žák, inkluze.

\section{Introduction}

According to the Institute of Information and Prognoses of Education (statistical data on individual integration of pupils from 1996-2008, 2009 and 2012), inclusion of pupils with special educational needs is becoming more and more common. This fact relates very closely to work and awareness of teachers at primary schools.

In relation to the above, we would like to outline the current situation at common primary schools and the level of teachers' knowledge of special educational needs of integrated pupils. Do teachers have sufficient information in the field of special educational needs? Are they interested in further education focused on special educational needs of pupils? Are they capable of providing adequate conditions for pupils within their school inclusion?

As stated in Borešová, Vančová (2003), the rapid growth of findings and information pool in all spheres of life makes it an obligation to enhance one's own education in all spheres and areas of human life. A person acquires fundamental information that is later intensified and complemented by additional information. At present, acquisition of new information is not exclusively tied to school education or to educational institutes but to life-long or continuing education. It depends on each person whether he/she is able to adapt and to what extent professionalism and personal growth is important for him/her.

We agree with the opinion expressed in the Memorandum of Long-life Education (2001) that long-life education is not the only aspect of education in professional preparation anymore; it must become one of many principles of providing additional possibilities and participation in education in its most diverse contexts. We believe that this vision should be materialized in the future.

The main objective is that this vision, to a sufficient extent within the system of lifelong education, facilitates access to new qualifications through prime-quality education and with the support of complex consultancy services in the course of the entire life and 
thus contributes to maintaining the highest possible employment and to increasing participation of the public in life-long education (Policy of Life-long Education, 2007).

\section{Research}

In general, it is expected that further education of teachers will result in deeper knowledge of special educational needs of pupils. The outcomes of our research uncovered weaknesses in awareness in this area but, on the other hand, showed sincere interest on the part of teachers in improving the quality and quantity of their knowledge. Inclusion is considered as a positive phenomenon in the today's society and teachers are willing to adapt to the new situation in respect to possible institutional education.

The research group consisted of 108 teachers from different primary school classes. Of these, 87 educators ( $80.6 \%$ ) graduated from a faculty of teaching and 20 educators $(18.5 \%)$ graduated from other faculties, most frequently faculties of arts. In some cases there were teachers who did not have any pedagogical education. It is generally known that, at present, young graduates from faculties of teaching find jobs more often in branches that are more favourable financially.

We found that the quality and quantity of knowledge in educators depended on the age of the respondents. Younger teachers probably attended a subject focused on special educational needs during their studies and, consequently, their knowledge (quality- as well as quantity-wise) in the given issue was at a higher level. In general, we believe that teachers have merely basic information on pupils with special educational needs, probably based on direct experience in the school environment. Also, teachers do not follow professional literature.

At most primary schools (65.7\%), there are at least one or two students with special educational needs. We believe that teachers' direct experience influences their evaluation of "the easiest and the most difficult" integrable pupils and, in the end, also the numbers of integrated pupils in a class. We are not sure whether certain questions (What is, in your opinion, an optimal number of pupils in a class including also pupils with special educational needs?) were understood correctly. Based on the responses, it is obvious that teachers do not know how the presence of a pupil with special educational needs affects the total number of pupils in a class when interpreted from the perspective of legal stipulations.

This happens despite the fact that $53 \%$ respondents teach a class with an integrated pupil and, thus, have personal experience. We learnt from the responses that the quality and quantity of related information were only superficial, and we believe that this can be caused by various circumstances, such as moral and financial motivation, overexertion of teachers, and non-existent adequate education activities. 
Older respondents, aged between 36 and 59 years, showed lack of interest in further education because they consider it unnecessary due to early retirement and/or termination of their teaching carrier.

It is highly probable that the level of knowledge in the area depends on one's achieved level of education; however, maybe even more, it can also be subject to the teachers' qualification. In our research, we monitored 20 respondents (18.5\%) who graduated from faculties different from faculties of teaching. Awareness of the issue is at the lowest level in such respondents when compared to qualified professionals.

When evaluating pupils with special needs, it was clearly evident that teachers (75\%) placed only those pupils into this group that had health impairments and learning and behavioural disorders. They failed to realize that this group also includes talented children and children from minorities.

We also deduced that teachers demonstrated problems with the terminology of individual disorders and impairments, and we very frequently encountered incorrect and colloquial terminology.

We also found out that teachers were interested in such education but it was highly conditioned by the fact whether such a pupil was/would be in their class $(34.3 \%$ respondents). On the other hand, only $17.6 \%$ of the respondents showed no interest in such further education. We assume that it is necessary to register this interest and provide the necessary support. However it is certain that this percentage of interest in further education shall be dependent on the length of the training, the contents, the demandingness, etc.

In line with the new trends and tendencies constantly reflected in recent pedagogy, the need and requirement for continual education is obvious, and we believe that this is one of the reasons for the interest of teachers in further education.

Table 1

Division of respondents by interests in institutional education with focus on special education

\begin{tabular}{|c|c|c|}
\hline & Number & $\%$ \\
\hline $\mathbf{1 .}$ & 16 & 14.8 \\
\hline $\mathbf{2 .}$ & 3 & 2.8 \\
\hline $\mathbf{3 .}$ & 11 & 10.2 \\
\hline $\mathbf{4 .}$ & 17 & 15.7 \\
\hline $\mathbf{5 .}$ & 37 & 34.3 \\
\hline $\mathbf{6 .}$ & 19 & 17.6 \\
\hline $\mathbf{7 .}$ & 5 & 4.6 \\
\hline $\mathbf{N}$ & 108 & 100 \\
\hline
\end{tabular}

Legend to the table

1 yes, in every case

2 yes, only in case of working hours

3 yes, in case of expenses being covered

4 yes, in case of my carrier and financial promotion

5 yes, in case such a child attends our school

6 not at all

7 no response 
It is encouraging to find that, despite differing motivation criteria, there is evident interest in further education. Educators feel this need due to the increasing number of integrated pupils as shown in real-life practice of primary schools.

\section{Conclusion}

In our paper, we concentrated on the level of knowledge of the subject of special educational needs and inclusion in teachers at primary schools.

We found that the knowledge of primary school teachers about pupils with special educational needs are merely superficial and are based on direct experience of teachers, hardly at an adequate professional level. The principal finding was that the teachers missed some important information and knowledge about special educational needs of an integrated pupil. This work aimed at identifying such areas, which are most affected by the prevailing weaknesses. We identified teachers' interest in further education in the field of special educational needs. Our work proves that it is important to continually enhance institutional education focused on the special educational needs of pupils, especially to increase the quality of professional-methodological as well as generallypedagogical preparation of future educators. Teachers have only basic information of inclusion and integrated pupils resulting from their assumptions, without personal contact with individual handicaps. Despite these facts, teachers are well aware of the shortcomings in their knowledge and show interest in further education in this area because, as stated by the teachers themselves, integration of pupils with special needs is an every-day experience now. We managed to give answers to all posed questions.

Nevertheless, we would like to refer to certain limitation of our findings. One possible factor, which reduces generalization of all teachers, is the fact that our results express exclusively the opinions of teachers that were actively teaching in the course of the realization of our research. Each year, however, a number of teachers leave the school professional environment due to retirement or change of profession, and these are replaced by new graduates with their own opinions, knowledge and information.

As a consequence of insufficient information in the area discussed, we cannot be sure whether teachers understood all terms and questions in the questionnaire correctly. At the same time, we are unable to interpret the honesty of some responses in respect to the pressure of new thoughts and to responses that are socially expected. 


\section{References}

Borešová, A., Vančová, A. (2003). Postgraduálne a celoživotné vzdelávanie špeciálnych pedagógov In Vančová, A., Habšudová, M. (Eds.). Príprava pedagógov pre deti so špeciálnymi výchovnovzdelávacími potrebami na prahu nového milénia. Bratislava: Sapientia.

Gavora, P. (2001). Úvod do pedagogického výskumu. $3^{\text {rd }}$ revised ed. Bratislava: Univerzita Komenského.

Heimlich, U. (2003). Integrative Pädagogik. Eine Einführung. Stuttgart: Verlag W. Kohlhammer.

Kasáčová, B. (2004). Učitel'ská profesia v trendoch teórie a praxe. Prešov: Metodicko-pedagogické centrum.

Pulda, M. (2000). Integrovaný žák se sluchovým postižením v základní škole. Brno: OL Print.

Tarcsiová, D. (2006). Zmeny v paradigmách pedagogiky sluchovo postihnutých a ich obraz v poradenskom systéme. In Efeta otvor sa 2005: Poradenstvo špeciálnej a liečebnej pedagogike. Martin: Osveta.

Internet resources:

Štatistické údaje o individuálnej integrácií žiakov od roku 1996-2012. [cit. 2009-05-06]. Retrieved from: http://www.uips.sk/sub/uips.sk/images/JC/rady/radtab18.xls

MŠMT, (2001). Memorandum o celoživotnom vzdelávaní. $1^{\text {st }}$ ed. Ministerstvo školstva SR v spolupráci s európskou komisiou Direktoriátom pre vzdelávanie a kultúru.

Stratégia celoživotného vzdelávania a celoživotného poradenstva, 2008. [cit. 2009-10-06]. Retrieved from: http://www.minedu.sk/index.php?lang=sk\&rootld=525

\section{Contact:}

Mgr. Ivana Horváthová

doc. Mgr. Dita Finková, Ph.D.

Ústav speciálněpedagogických studií

Žižkovo náměstí 5

77140 Olomouc

E-mails: horvathova-ivana@seznam.cz, ditafinkova@seznam.cz 